\title{
Profitability and Comparative Advantage of Onion (Allium cepa) Production in Bangladesh: An Economic Study in Some Selected Areas
}

\author{
Arifa Anjum and Basanta Kumar Barmon* \\ Department of Economics, East West University, Dhaka-1212, Bangladesh \\ *Corresponding author and Email: bkbarmon@yahoo.com
}

Received: 19 September 2017

Accepted: 22 December 2017

\begin{abstract}
The present study attempted to estimate the profitability, domestic resource cost (DRC) and problems and prospects of onion production in the study areas. Both primary and secondary data were used in this study. Sample survey was carried out in two selected areas under Kushtia and Jhenaidah districts. A total of 110 onion producers were selected randomly of which 70 producers were from Kushtia and the remaining 40 producers were from Jhenaidah. The study showed that, on an average, total costs of onion production per hectare were about Tk. 150,097 and 116,831 in Kushtia and Jhenaidah district, respectively. The benefit cost ratios (BCR) of onion production were 2.02 and 1.83 in Kushtia and Jhenaidah district, respectively. The results of profitability and BCR show that onion is a profitable crop in Bangladesh. The domestic resource costs (DRC) were 0.47 in Kushtia and 0.52 in Jhenaidah, which indicate that Bangladesh has comparative advantage in onion production. The coefficients of the production function show that farm area, irrigation, pesticides, seeds, chemical fertilizers (TSP) and labor were statistically significant affecting factors of onion production and it shows constant returns to scale. The onion producers faced some production, technological and marketing related problems in the study areas. The government should therefore, take necessary policies for further development of onion production in Bangladesh.
\end{abstract}

Keywords: Onion production, profitability, benefit-cost ratio (BCR), comparative advantage, domestic resource cost (DRC).

\section{Introduction}

Bangladesh is basically an agricultural country. Agriculture is the largest and important economic sector in Bangladesh because of its production environments such as weather condition, soil fertility, water availability and comparatively cheaper labor supply. Most of the people in rural areas depend on agriculture for earning their daily livelihood through growing different crops, livestock and fisheries etc.
Onion (Allium cepa) is one of the most significant profitable vegetable crops, which is used as spices in our daily meal in Bangladesh. Besides Bangladesh, it has also huge demand all over the world. It can be used in both mature and immature level as vegetable and spices, and increases the taste of food by its flavor that contains protein, calcium, carbohydrates and vitamin C. It is also used as medicine to recover from insect injury and raw throat (Bose and Som, 1990). In Bangladesh, onion ranks top 
among all the spice crops in production (BBS, 2008). In terms of world production, onion ranks second among the 15 vegetables specified by Food and Agriculture Organization (Pathak, 2000). Onion is cultivated all over the country extensively in winter season. Onion production was 1,704,402 metric ton in 2014-2015 in Bangladesh (BBS, 2015). But it may not fulfil the demand for our country due to increase in population day by day. As such, importation of onion from outside is being done very often (Haque et al., 2011). In 2014-2015, Bangladesh imported about 42,340 metric tons of onion and shallots (BBS, 2016). Bangladesh has supportive climate and adequate resources for onion production, processing, and marketing etc. (Bapari et al. 2016). In Kushtia and Jhenaidah the cultivation of onion was 21,714 acres and 13,021 acres and the production was 90,562 metric tons and 50982 metric tons respectively 2015 (BBS, 2016). Government took steps to produce 1.9 million metric tons of onion in 2017.

Some research have been conducted sporadically on the adoption practices and cultivation of onion (Anik, and Salam, 2015), economic assessments such as profitability, gross margin (Mahmood, 1995; Shaha, 1999; Hasan, 2010; Haque et al., 2011; Miah and Rashid, 2015; Bapari et al., 2016; Grema and Gashua, 2014), measurement of technical efficiency (Baree, 2012; Haile, 2015; Mari and Lohano, 2007; Banai et al., 2013), constraints to production and marketing (Ali et al., 2015), forecasting of onion production in Bangladesh (Hossain et al., 2017). Some researchers also have conducted research on different aspects of onion cultivation in Bangladesh such as return to investment and development using secondary data (Hasan et al., 2009), planting time and mulching effect on onion development and seed production of onion cultivation of Bangladesh (Anisuzzaman et al., 2009). However, the estimation of profitability, comparative advantages, and problems and prospects of onion production in Bangladesh has been received less attention. Therefore, the present study estimates the financial, economic profitability and comparative advantage of onion production. In addition, it also explores the problems and prospects of onion production in Bangladesh. Therefore, the findings of the study will help the policy makers and researchers to make appropriate policies and suggestions for the further development of onion production in Bangladesh.

\section{Methodology}

\subsection{Sources of data}

Based on the objectives of the study, both primary data and secondary data were used in this study. Kustia and Jhenaidah districts were purposively selected because a large number of farmers in these areas are engaged in onion cultivation in winter season like other places in Bangladesh. Moreover, the environments, weather conditions as well as soil are suitable for onion production. A total of 110 farms (70 farmers from Kushtia district and 40 from Jhenaidah district) were randomly selected and directly interviewed. The necessary information of inputs and outputs on onion production was collected using structured questionnaire that covers the crop calendar 2016.

\subsection{Analytical techniques}

\subsubsection{Profitability analysis of onion cultivation} To estimate the profitability of onion production, gross return, gross margin, net return and benefit cost ratio were calculated. The opportunity cost of land use and family supplied labor were calculated as fixed cost. Irrigation cost, pesticide cost, land preparation cost, seed and seedling cost, fertilizer cost and hired labor cost were calculated based on current market inputs price and were considered as variable cost. Total cost was estimated by adding variable cost and fixed cost. The output of onion and their prices were taken in to consideration in estimating gross return. 
To estimate the cost of onion cultivation, the following equations were used:

$$
\begin{aligned}
& V C=\sum\left(X_{i} P_{i}\right) \\
& T C=V C+F C
\end{aligned}
$$

Where,

$\mathrm{TC}=$ Total cost of onion production $(\mathrm{Tk} / \mathrm{ha})$

$\mathrm{VC}=$ Variable cost of onion $(\mathrm{Tk} / \mathrm{ha})$

$\mathrm{FC}=$ Fixed cost of onion $(\mathrm{Tk} / \mathrm{ha})$

$\mathrm{X}_{\mathrm{i}}=$ Quantity of inputs $(\mathrm{Kg} / \mathrm{ha})$ except irrigation and pesticides; irrigation and pesticides used as (Tk/ha) for onion production

$P_{i}=$ Price of inputs $(\mathrm{Tk} / \mathrm{kg})$ used for onion

To estimate the profitability of onion production, the following equations were used:

$$
\text { Gross return, } G R=\sum Y_{i} P_{i}
$$

Net return, $N R=G R-T C$

Gross margin, $G M=G R-V C$

Benefit $\cos t$-ratio, $B C R=\frac{G R}{T C}$

Where,

$\mathrm{GR}=$ Gross return from onion $(\mathrm{Tk} / \mathrm{ha})$

$\mathrm{NR}=$ Net return from onion $(\mathrm{Tk} / \mathrm{ha})$

$\mathrm{GM}=$ Gross margin from onion $(\mathrm{Tk} / \mathrm{ha})$

$\mathrm{Y}=$ Quantity of output of onion $(\mathrm{Kg} / \mathrm{ha})$

$\mathrm{P}=$ Price of onion $(\mathrm{Tk} / \mathrm{kg})$

\subsubsection{Benefit Cost Ratio (BCR)}

Benefit cost ratio (BCR) is used to indicate the relationship between cost and benefit of any project in monetary terms. Higher BCR indicates higher return from the production. Usually total cost is used for calculating BCR. But we also used variable cost for calculating BCR.

To estimate the Benefit-cost ratio (BCR), the following equations were used.

When we used total cost,

$$
\text { Benefit } \cos t-\text { ratio, } B C R=\frac{T R}{T C}
$$

When we used variable cost,
Benfit $\cos t-$ ratio, $B C R=\frac{T R}{V C}$

If the BCR is higher than the cost, the project is considered as a profitable investment.

\subsubsection{Domestic Resource Cost (DRC):}

Domestic Resource Cost (DRC) was calculated to figure out the efficiency of onion production, related to the comparative advantage. It determines the ratio of shadow value of its inputs to outputs domestically to save the foreign exchange. The following equation was used to estimate the Domestic resource cost (DRC) of onion production (Bruno, 1965; Krueger, 1966; Monake, 1981):

$D R C=\frac{\sum D_{i} V_{i}}{B-\sum T_{i} V_{i}}$

Where,

$\mathrm{D}_{\mathrm{i}}=$ Quantity of domestic resources and nontraded inputs for onion production per metric ton

$\mathrm{V}_{\mathrm{i}}=$ Price of domestic resources and non-traded inputs for onion production ( $\mathrm{Tk} / \mathrm{mt}$ )

$\mathrm{B}=$ Border price of onion $(\mathrm{Tk} / \mathrm{mt})$

$\mathrm{T}_{\mathrm{i}}=$ Quantity of tradable inputs for onion production per metric ton

$\mathrm{V}_{\mathrm{i}}=$ Border price of tradable inputs for onion production $(\mathrm{Tk} / \mathrm{mt})$

If domestic resource cost is less than one $(\mathrm{DRC}<1)$, it implies that benefits are positive, the country can produce the crop domestically and save the foreign exchange. On the other hand, if domestic resource cost is greater than one (DRC $>1)$, benefits are negative; the country should not produce the crop domestically and should rather import.

\subsubsection{Estimation of Cobb-Douglas production function}

In order to estimate the contribution of different factors of onion production in the study farms, Cobb-Douglas production function was employed. 


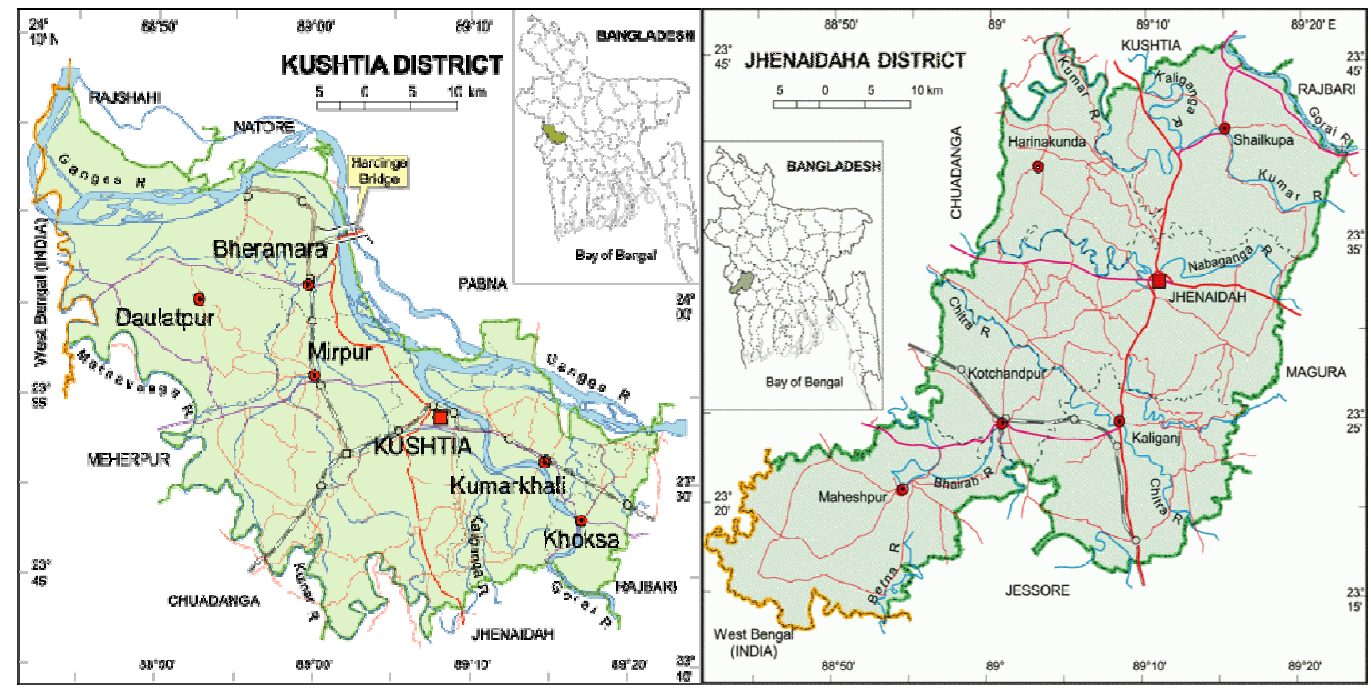

Figure 1. Map of study districts in Bangladesh.

In this respect, the double- $\log \mathrm{C}-\mathrm{D}$ function is given as:

$$
\begin{aligned}
\ln Y= & \beta_{0}+\beta_{1} \ln X_{1}+\beta_{2} \ln X_{2}+\beta_{3} \ln X_{3}+\beta_{4} \ln X_{4}+\beta_{5} \ln X_{5}+\beta_{6} \ln X_{6}+\beta_{7} \ln X_{7}+\beta_{8} \ln X_{8}+ \\
& \beta_{9} \ln X_{9}+\beta_{10} \ln X_{10}+u_{i}
\end{aligned}
$$

Where,

$\mathrm{Y}=$ Output of onion $(\mathrm{kg})$

$\mathrm{X}_{1}=$ Area $($ acre $)$

$\mathrm{X}_{2}=$ Irrigation (number of application)

$\mathrm{X}_{3}=$ Pesticide (number of application)

$\mathrm{X}_{4}=$ Seed $(\mathrm{kg})$

$\mathrm{X}_{5}=$ Manure (ton)

$\mathrm{X}_{6}=$ Urea $(\mathrm{kg})$

$\mathrm{X}_{7}=\mathrm{TSP}(\mathrm{kg})$

$\mathrm{X}_{8}=\mathrm{MP}(\mathrm{kg})$

$\mathrm{X}_{9}=$ Gypsum $(\mathrm{kg})$

$\mathrm{X}_{10}=$ Labor (man-day)

$\beta_{0}$ is intercept and $\beta_{1}, \beta_{2}, \beta_{3}, \beta_{4}, \beta_{5}, \beta_{6}, \beta_{7}, \beta_{8}, \beta_{9}$, $\beta_{10}$ are the coefficients of the regression to be estimated. $u_{i}$ is the error term which is independently distributed with zero mean and constant variance. In addition, one sample t-test was used to find out the significance level of the variation of variables in the regression model.

\section{Results and Discussion}

\subsection{Economic analysis of onion production}

In estimating the cost of onion production both variable costs and fixed costs were considered. On the other hand, the net return or profit was estimated through considering the revenue gained from onion production.

\subsubsection{Variable cost}

Normally variable cost is the largest components of the total cost of any agricultural production system. The cost of irrigation, pesticides, land preparation, seed and seedling, fertilizers, manure, hired labour and interest on operating capital were included in the variable costs in onion production. All the inputs were measured in terms of per hectare basis. The average variable costs of per hectare onion production were presented in Table 1 . The average variable cost of per hectare onion production was about Tk.105,137 and Tk. 116,657 in Kushtia and 
Jhenaidah district, respectively. The average hired labour cost was about $24 \%$ and $26 \%$ of the total cost of production in Kushtia and Jhenaidah, which was the highest cost item in onion production in both districts (Table 1).

\subsubsection{Fixed cost}

The opportunity cost of family labour and the land used in onion production were considered as fixed cost. The opportunity cost of family labour was calculated as the daily wage of hired male and female labour. The average fixed cost of per hectare onion production was about Tk.44,961 and Tk.46,901 in Kushtia and Jhenaidah, respectively. The average cost of land use and family labour were $9.6 \%, 8.65 \%$ and $20.4 \%, 20.1 \%$ of the total cost in Kushtia and Jhenaidah, respectively (Table 1).

\subsubsection{Total cost}

Total cost includes both the variable cost and fixed cost in onion production as appeared in Table 1. On an average, the total cost of per hectare onion production in Kushtia district and
Jhenaidah district was about Tk. 150,097 and Tk. 163,558 , respectively. The average variable cost was $70 \%$ and $71.3 \%$ and the average fixed cost was $30 \%$ and $28.7 \%$ of the total cost of onion production in Kushtia and Jhenaidah, respectively. On an average, the average variable cost was more than two times higher than the average fixed cost in per hectare onion production in both districts.

\subsubsection{Gross return, Gross margin, Net return and Rate of return}

The gross return, gross margin, net return and rate of return of onion production have been presented in Table 2. In Kushtia, the gross return (GR), gross margin (GM) and net return (NR) were about Tk. 266,929, Tk. 161,792 and Tk. 116,831 , respectively whereas it were about Tk. 282035, Tk. 165,378 and Tk. 118,477 in Jhenaidah district. The figures show that on an average, per hectare cost and returns of onion production were almost same in both districts mainly because of the same production environments of two adjacent districts.

Table 1. Structure of cost of onion production in the study areas, 2016

\begin{tabular}{lcccc}
\hline \multirow{2}{*}{ Particulars } & Kushtia & \multicolumn{3}{c}{ Jhenaidah } \\
\cline { 2 - 5 } & Cost (Tk/ha) & $\%$ & Cost (Tk/ha) & $\%$ \\
\hline A. Variable cost & $\mathbf{1 0 5 1 3 6 . 9}$ & 70.0 & $\mathbf{1 1 6 6 5 6 . 6}$ & 71.3 \\
Irrigation & 12128.9 & 8.1 & 12375.9 & 7.6 \\
Pesticide & 4422.1 & 2.9 & 8165.3 & 5.0 \\
Land preparation & 9873.8 & 6.6 & 11147.4 & 6.8 \\
Seed \&Seedling & 13559.0 & 9.0 & 13978.9 & 8.5 \\
Fertilizers & 13835.1 & 9.2 & 16807.1 & 10.3 \\
Manure & 4551.2 & 3.0 & 0.0 & 0.0 \\
Hired labour & 36135.0 & 24.1 & 42385.3 & 25.9 \\
Interest on capital & 10631.8 & 7.1 & 11796.7 & 7.2 \\
B. Fixed cost & $\mathbf{4 4 9 6 1 . 0}$ & 30.0 & $\mathbf{4 6 9 0 1 . 3}$ & 28.7 \\
Land use & 14354.9 & 9.6 & 14080.9 & 8.6 \\
Family labour & 30606.1 & 20.4 & 32820.4 & 20.1 \\
C. Total cost (A+B) & $\mathbf{1 5 0 0 9 7 . 9}$ & 100.0 & $\mathbf{1 6 3 5 5 7 . 9}$ & 100.0 \\
\hline
\end{tabular}


Table 2. Profitability of per hectare onion production in the study areas, 2016

\begin{tabular}{lccc}
\hline Particulars & Kushtia & Jhenaidah & t-ratio \\
\hline 1. Yield (Kg/ha) & $11573.3 * * *$ & $12315.0 * * *$ & -1.43 \\
2. Price (Tk/kg) & $22.4 * * *$ & $22.5 * * *$ & - \\
3. Gross return (Tk/ha) & $266928.9 * * *$ & $282034.7 * * *$ & -1.26 \\
4. Total variable cost (Tk/ha) & $105136.9 * * *$ & $116656.6 * * *$ & -1.42 \\
5. Total cost (Tk/ha) & $150097.9 * * *$ & $163557.9 * * *$ & -1.21 \\
6. Gross margin (Tk/ha) (3-4) & $161792.0 * * *$ & $165378.1 * * *$ & -0.76 \\
7. Net return (Tk/ha) (3-5) & $116831.0 * * *$ & $118476.8 * * *$ & -0.65 \\
8. Rate of return (Tk/ha) & & & \\
Over variable cost (3/4) & $2.53 * * *$ & $2.42 * * *$ & 1.24 \\
Over total cost (3/5) & $1.78^{* * *}$ & $1.72 * * *$ & 1.12 \\
\hline
\end{tabular}

Note: $* * *$ represents statistically significant at $1 \%$ level.

Table 3. Economic profitability and domestic resource cost of onion production

\begin{tabular}{lcc}
\hline \multicolumn{1}{c}{ Particulars } & \multicolumn{2}{c}{ (Tk./ha) } \\
\cline { 2 - 3 } & 13835.09 & Jhenaidah \\
\hline A. Cost of inputs (traded)* & 125631 & 16807.09 \\
B. Costs of inputs (non-traded) & & 134954.2 \\
$\quad$ \& domestic resources & 9873.79 & \\
Land preparation cost & 14354.87 & 11147.43 \\
Land rent & 13559.01 & 14080.87 \\
Seed cost & 12128.87 & 13978.89 \\
Irrigation cost & 4422.12 & 12375.89 \\
Pesticide cost & 4551.25 & 8165.34 \\
Manure & 66741.04 & 0 \\
Human labour & 139466.1 & 75205.73 \\
C. Total cost of input (A+B) & 281588.41 & 151761.3 \\
D. Price of output** & 142122.3 & 276982.43 \\
E. Net profit (D-C) & 2.02 & 125221.1 \\
F. BCR (D/C) & 267753.3 & 1.83 \\
G. Value added (tradable) (D-A) & 0.47 & 260175.3 \\
H. DRC (B/G) & & 0.52 \\
\hline
\end{tabular}

* Traded inputs included Urea, TSP, MP, Gypsum \& ZN; **Border price at farm gate

The data in table 2 also indicate that average rate of return over variable cost was found at 2.53 and over total cost were 1.78 in Kushtia district whereas it was 2.42 and 1.72 in Jhenaidah district. These results indicated that, in terms of rate of return from onion production, the crop is profitable in both districts. The average yield of onion was estimated at $11573.3 \mathrm{~kg}$ in Kushtia and $12315.0 \mathrm{~kg}$ in Jhenaidah district. The yield, gross return, total cost, gross margin, net return, and rate of return over variable and total cost of onion production were significantly varied (statistically significant at $1 \%$ ) within the sampled producers in both Kushtia and 
Jhenaidah district. However, there were no significance mean difference exists between the producers in Kushtia and Jhenaidah district.

\subsubsection{Analysis of comparative advantage of onion production based on DRC method}

A country has a comparative advantage when it can produce a particular crop at lower cost than any other county. A country should produce more of those goods which have lower relative cost of production on that country. On the other side, it should reduce the production of those goods which can be imported at lower relative price. Domestic producers' prices were considered as the farm gate prices of onion and the import prices of onion were considered in world prices for calculating the comparative advantage of onion production in the country.

Domestic resource cost (DRC) indicates the comparative advantage of onion production. If domestic resource cost is greater than one, the country loses foreign exchange through domestic production and there are negative benefits of production. If domestic resource cost is less than one, the country can save foreign exchange and domestically produce the crop. The domestic resource cost (DRC) of onion production in Kustia and Jhenaidah was presented in Table 3. The estimated DRC of onion production in Kushtia district was 0.47 and in Jhenaidah district was 0.52. DRC of onion crop is less than one in both districts. It means that Bangladesh has comparative advantage in producing onion.

In an earlier study, Miah and Rashid (2015) conducted a research on profitability and comparative advantage of oilseed production in Bangladesh, where they used DRC method to evaluate the comparative advantage of oilseeds in Bangladesh. They found that Bangladesh has comparative advantage of producing oilseeds. Yercan and Isikli (2009) conducted a research on domestic resource cost (DRC) approach for international competitiveness of Turkish horticultural products, where they used DRC to estimate the competitive advantage of Turkish horticultural sector. They found that tomato and tangerine production were more competitive between 2000 and 2004 .

Table 4. Definitions of variables in Cobb-Douglas production function

\begin{tabular}{ll}
\hline Variables & \multicolumn{1}{c}{ Definition } \\
\hline Dependent variable & Quantity of onion yield in per farm, measured in $\mathrm{kg}$. \\
\hline Output & \\
\hline Independent variable & Farm area, measured in acre. \\
\hline Farm area & Irrigation used in onion cultivation, measured in number. \\
Irrigation & Pesticide used in onion cultivation, measured in number. \\
Pesticide & Quantity of seed in onion production, measured in $\mathrm{kg}$. \\
Seed & Quantity of manure in onion production, measured in ton. \\
Manure & Quantity of urea in onion production, measured in $\mathrm{kg}$. \\
Urea & Quantity of TSP in onion production, measured in $\mathrm{kg}$. \\
TSP & Quantity of MP in onion production, measured in $\mathrm{kg}$. \\
MP & Quantity of Gypsum in onion production, measured in $\mathrm{kg}$. \\
Gypsum & Labor engaged in onion production, measured in man-day. \\
Labor &
\end{tabular}


Table 5. Descriptive statistics of dependent and independent variables in Cobb-Douglas production function

\begin{tabular}{|c|c|c|c|c|c|c|c|c|}
\hline \multirow[b]{2}{*}{ Variables } & \multicolumn{4}{|c|}{ Kushtia District } & \multicolumn{4}{|c|}{ Jhenaidah District } \\
\hline & Mean & SD & Min & Max & Mean & SD & Min & Max \\
\hline Farm area & $0.64 * * *$ & 0.46 & 0.09 & 2.31 & $0.58 * * *$ & 0.37 & 0.08 & 1.65 \\
\hline Irrigation & $2.84 * * *$ & 0.63 & 2 & 6 & $3.13 * * *$ & 0.85 & 1 & 5 \\
\hline Pesticide & $3.17 * * *$ & 1.09 & 2 & 7 & $3.43 * * *$ & 1.55 & 1 & 8 \\
\hline Seed & $2.29 * * *$ & 1.63 & 0.5 & 8 & $1.85 * * *$ & 1.37 & 0.5 & 7 \\
\hline Manure & $3.81 * * *$ & 3.07 & 0 & 15 & 0.00 & 0.00 & 0 & 0 \\
\hline Urea & $95.67 * * *$ & 82.24 & 6 & 350 & $72.25 * * *$ & 56.23 & 20 & 300 \\
\hline TSP & $45.53 * * *$ & 37.97 & 6 & 200 & $83.88^{* * *}$ & 47.10 & 20 & 200 \\
\hline MP & $38.17 * * *$ & 36.98 & 0 & 200 & 0.00 & 0.00 & 0 & 0 \\
\hline Gypsum & $42.27 * * *$ & 47.75 & 0 & 300 & $29.75 * * *$ & 40.10 & 0 & 200 \\
\hline Labor & $64.99 * * *$ & 34.42 & 16 & 165 & $65.78 * * *$ & 32.88 & 18 & 168 \\
\hline Output & $2922.93 * * *$ & 2174.78 & 560 & 12600 & $2754.25 * * *$ & 2082.73 & 740 & 12160 \\
\hline
\end{tabular}

Source: Field survey, 2017. Notes: Sample size: (1) 70 and 40 in Kushtia and Jhenaidah district, respectively.

(2) $* * *$ indicates statistically significance at $1 \%$ level.

Table 6. Estimates of Cobb-Douglas production function for onion production

\begin{tabular}{|c|c|c|c|c|}
\hline \multirow[b]{2}{*}{ Variables } & \multicolumn{2}{|c|}{ Kushtia District } & \multicolumn{2}{|c|}{ Jhenaidah District } \\
\hline & Coefficients & t-ratio & Coefficients & t-ratio \\
\hline Constant & $8.749 * * *$ & 10.31 & $6.674 * * *$ & 8.76 \\
\hline Farm area $\left(\ln \mathrm{X}_{1}\right)$ & $0.538 * * *$ & 5.57 & $0.574 * * *$ & 6.65 \\
\hline Irrigation $\left(\ln \mathrm{X}_{2}\right)$ & 0.089 & 1.13 & $0.081^{*}$ & 1.96 \\
\hline Pesticide $\left(\ln X_{3}\right)$ & $0.014 * *$ & 2.12 & 0.021 & 1.45 \\
\hline Seed $\left(\ln \mathrm{X}_{4}\right)$ & $0.197 * * *$ & 3.08 & $0.216^{* *}$ & 2.16 \\
\hline Manure $\left(\ln \mathrm{X}_{5}\right)$ & 0.019 & 0.37 & - & - \\
\hline Urea $\left(\ln \mathrm{X}_{6}\right)$ & -0.043 & -0.79 & -0.039 & -0.87 \\
\hline $\operatorname{TSP}\left(\ln X_{7}\right)$ & $0.075 * * *$ & 3.17 & 0.055 & 1.23 \\
\hline $\mathrm{MP}\left(\ln \mathrm{X}_{8}\right)$ & -0.024 & -0.38 & -0.034 & -0.55 \\
\hline Gypsum $(\ln X 9)$ & -0.017 & -0.32 & -0.021 & -0.67 \\
\hline Labor $(\ln X 10)$ & $0.131^{*}$ & 1.97 & $0.163^{* *}$ & 2.34 \\
\hline Resturns to scale (RTS) & 0.979 & & 1.016 & \\
\hline $\mathrm{R}^{2}$ & 0.76 & & 0.72 & \\
\hline F-value & $176.45^{* * *}$ & & 145.43 & \\
\hline
\end{tabular}

indicate statistically significance at $1 \%, 5 \%$ and $10 \%$ level, respectively. 
Ismail et al. (2009) carried out a study on the impact of DRC on the comparative advantages of Iran crude steel sector where they investigated the comparative advantage of blast furnace $(\mathrm{BF})$ and direct reduced iron technology (DRI) by using DRC method. They found that at a point of time DRC can measure comparative advantage. Stryker et al. (2009) carried out a study for domestic resource cost analysis of Azerbaijan. They used DRC analysis to evaluate 30 sub sectors of the Azerbaijani economy. They found both comparative advantage and comparative disadvantage in different sub sectors and markets by calculating DRC.

\subsection{Estimation of Cobb-Douglas production function}

\subsubsection{Definition of the variables}

Cobb-Douglas production function represents the relationship between inputs and output of the production process. The definitions of variables used in Cobb-Douglas production function are given in Table 4.

\subsubsection{Summary statistics of the variables used in Cobb-Douglas production function}

Table 5 represents the descriptive statistics of dependent and independent variables used in Cobb-Douglas production function. The average number of irrigation of onion production in Kushtia district was found at 2.84 ranging from 2 to 6 with a standard deviation of 0.63 and it was statistically significant at $1 \%$ level. On an average, mean number of the application of pesticides used was estimated at 3.17 that vary between 2 and 7 with standard deviation of 1.09 and it was statistically significant at $1 \%$ level. The average quantity of seed was calculated at $2.29 \mathrm{~kg}$ which was varied between $0.5 \mathrm{~kg}$ and 8 $\mathrm{kg}$ with standard deviation of $1.63 \mathrm{~kg}$ and it was statistically significant at $1 \%$ level. The mean amount of urea was found at $95.67 \mathrm{~kg}$ ranging from $6 \mathrm{~kg}$ to $350 \mathrm{~kg}$. The average quantity of TSP was found at $45.53 \mathrm{~kg}$ which ranging from 6 $\mathrm{kg}$ to $200 \mathrm{~kg}$ with standard deviation of $37.97 \mathrm{~kg}$ and it was statistically significant at $1 \%$ level. The mean quantity of MP was and gypsum was $38.17 \mathrm{~kg}$ and $42.27 \mathrm{~kg}$, respectively. The mean labor (man-day) was estimated at 64.99 which lie between 16 and 165 with a standard deviation of 34.42 and it was statistically significant at $1 \%$ level. The average yield of onion in per farm was found at $2922.93 \mathrm{~kg}$ and range between minimum $560 \mathrm{~kg}$ and maximum 12,600 kg with a standard deviation of $2174.78 \mathrm{~kg}$ and it was statistically significant at $1 \%$ level. The summary statistics of inputs used and output of onion cultivation in Jhenaidah district was also presented in table 5. All inputs used in onion production and output produced varied significantly among the onion producers in both Kushtia and Jhenaidah district.

\subsubsection{Analysis of Cobb-Douglas production function}

Cobb-Douglas production was used to determine the contribution of the independent variables used in onion production in Kushtia and Jhenaidah district. The results of the CobbDouglas production function are presented in table 6. Before analyzing the data, multicollinearity test was performed and found no multicollinearity in the data. The figures in the table show that the coefficients of farm area, pesticides, TSP, seed and labor were positive and all were statistically significant. This indicates that $1 \%$ increase in those input keeping other inputs remaining constant would increase the production of onion by $0.538 \%, 0.014 \% 0.197 \%$, $0.075 \%$ and $0.131 \%$, respectively, indicating that farm area, irrigation, pesticides, seed, TSP, and labor had positive and significant positive impact on onion production in Kushtia district. The other main input irrigation had also positive impact but it was statistically insignificant. The coefficients of urea (-0.043), MP (-0.024) and gypsum $(-0.017)$ were negative and irrigation (0.089) and manure (0.019) were positive and these were statistically insignificant. On the other hand, the farm area, irrigation, seed and labor had statistically significant impacts on onion production in Jhenaidah district except pesticides, manure, urea, TSP and Gypsum. The returns to scale of onion production was the summation of the coefficients of all inputs was about 0.979 and 1.016 in Kushtia and Jhenaidah 
district, respectively, which indicates that the Cobb-Douglas production exhibited almost constant return to scale and lied in the second stage of the production. The coefficients of determination $\left(\mathrm{R}^{2}\right)$ that represent the goodness of fit of the production function were 0.76 and 0.72 in Kushtia and Jhenaidah, respectively. This indicate that, the variables included in the production function explained about $76 \%$ and $72 \%$ yield variability of the sampled onion farms and it was statistically significant at $1 \%$ level.

\subsection{Problems and constraints of onion production}

The producers in any agricultural production system faces many problems related to production, marketing, and technical. The onion producers face some problems in onion cultivation. They face production, marketing and technological problems which are discussed in this section.

\subsubsection{Production problems}

The production problems of onion producers are given in Table 7. About $80 \%$ sampled producers from Kushtia and $75 \%$ sampled producers from Jhenaidah mentioned that the price of inputs is high. About fifty-four percent (54\%) and 60\% producers from Kushtia and Jhenaidah confirmed that about the lack of supply of insecticides and pesticides during the proper application time in the stages of onion cultivation. In Kushtia and Jhenaidah, the sampled producers faced higher labour cost
(50\% and $55 \%$ ), lack of capital (40\% and $40 \%$ ), climate change problem (24\% and $45 \%)$ and lack of high productive seed (30\% and 25\%) respectively. They also faced problems when they cannot specify crop disease and separate of land.

\subsubsection{Marketing problems}

Marketing of agricultural products in any developing county is severe mainly because of the biological characteristics of the product such as perish ability and storing. Marketing related problems of onion have been presented in Table 8. Most of the producers from both districts expressed that the price of onion is low in farm gate. This problem was mentioned by majority of the farmers in both the districts. The producers complained against market structure such as maintenance $(50 \%$ and $25 \%$ ), market regulations (47\% and $20 \%)$ and availability of markets $(40 \%$ and $30 \%$ ) from Kushtia and Jhenaidah, respectively. The producers very often face transportation problem.

\subsubsection{Technical problems}

The stated technical problems are summarized in Table 9. Most of the producers expressed their problems for lack of modern machines and modern technologies. The producers from Kushtia and Jhenaidah also mentioned their technical problems as non-availability of cold storage (44\% and 50\%), lack of experienced labour (24\% and 15\%) and lack of training program $(31 \%$ and $30 \%)$, respectively.

Table 7. Production Problems

\begin{tabular}{lcccc}
\hline \multirow{2}{*}{\multicolumn{1}{c}{ Problems }} & \multicolumn{2}{c}{ Kushtia District } & \multicolumn{2}{c}{ Jhenaidah District } \\
\cline { 2 - 5 } & Number & $\%$ & Number & $\%$ \\
\hline Supply of high productive seed & 21 & $30 \%$ & 10 & $25 \%$ \\
High labour cost & 35 & $50 \%$ & 22 & $55 \%$ \\
Specifying crop disease & 19 & $27 \%$ & 8 & $20 \%$ \\
Supply of insecticides \& pesticides & 38 & $54 \%$ & 24 & $60 \%$ \\
Climate change & 17 & $24 \%$ & 18 & $45 \%$ \\
High price of inputs & 56 & $80 \%$ & 30 & $75 \%$ \\
Capital & 28 & $40 \%$ & 16 & $40 \%$ \\
Separate land & 14 & $20 \%$ & 8 & $20 \%$ \\
\hline
\end{tabular}

Source: Field survey, 2017. 
Table 8. Marketing Problems

\begin{tabular}{lcccc}
\hline \multirow{2}{*}{ Problems } & \multicolumn{2}{c}{ Kushtia District } & \multicolumn{2}{c}{ Jhenaidah District } \\
\cline { 4 - 5 } \cline { 3 - 5 } & Number & $\%$ & Number & $\%$ \\
\cline { 4 - 5 } Transportation & 14 & $20 \%$ & 14 & $35 \%$ \\
Available markets & 28 & $40 \%$ & 12 & $30 \%$ \\
Market regulations & 33 & $47 \%$ & 8 & $20 \%$ \\
Market maintenance & 35 & $50 \%$ & 10 & $25 \%$ \\
Low price of onion & 49 & $70 \%$ & 24 & $60 \%$ \\
\hline
\end{tabular}

Source: Field survey, 2017.

Table 9. Technical Problems

\begin{tabular}{lcccc}
\hline \multirow{2}{*}{ Problems } & \multicolumn{2}{c}{ Kushtia District } & \multicolumn{2}{c}{ Jhenaidah District } \\
\cline { 2 - 4 } & Number & $\%$ & Number & $\%$ \\
\hline Lack of improved machines & 56 & $80 \%$ & 26 & $65 \%$ \\
Lack of cold storage & 31 & $44 \%$ & 20 & $50 \%$ \\
Lack of experienced labour & 17 & $24 \%$ & 6 & $15 \%$ \\
Lack of training & 22 & $31 \%$ & 12 & $30 \%$ \\
Lack of modern technology & 45 & $64 \%$ & 18 & $45 \%$ \\
\hline
\end{tabular}

Source: Field survey, 2017.

Table 10. Suggestions of producers for onion production

\begin{tabular}{lcccc}
\hline \multirow{2}{*}{ Suggestions } & \multicolumn{2}{c}{ Kushtia District } & \multicolumn{2}{c}{ Jhenaidah District } \\
\cline { 2 - 5 } & Number & $\%$ & Number & $\%$ \\
\hline Reduce inputs price in market & 42 & $60 \%$ & 20 & $50 \%$ \\
Availability of inputs in market & 35 & $50 \%$ & 22 & $55 \%$ \\
Increase onion price in market & 54 & $77 \%$ & 26 & $65 \%$ \\
Availability of proper market place & 26 & $37 \%$ & 12 & $30 \%$ \\
Training program for producers & 21 & $30 \%$ & 9 & $22 \%$ \\
Need more developed machine for & 38 & $54 \%$ & 24 & $60 \%$ \\
cultivation & 14 & $20 \%$ & 8 & $20 \%$ \\
Provide loan & 17 & $24 \%$ & 4 & $10 \%$ \\
Provide storage facilities & 56 & $80 \%$ & 30 & $75 \%$ \\
Government should take steps for & & & & \\
onion production & & & & \\
\hline Source: Fien survey, 2017. & & & & \\
\hline
\end{tabular}

Source: Field survey, 2017.

Therefore, it may be concluded that most of the sampled onion producers faced production, marketing and technical problems that hinder optimal level of production of onion in the study area.

\subsubsection{Suggestions by the onion producers}

The sample onion producers provided few suggestions which may be helpful for better production of onion in the study areas. The suggestions made by the sampled farmers in Kushtia and Jhenaidah were present in Table 10.

Most of the producers suggested that onion price should increase in market and Government should take necessary steps such as available all inputs in the market at lower price for increasing onion production. The producers also suggested 
that the input price should be reduced and make availability of inputs in the markets. In addition, they recommended that proper market place for onion, efficient training program for the producers; loan and cold storage facilities will improve and increase onion production.

\section{Conclusions}

On an average, per hectare gross return (GR), gross margin (GM) and net return (NR) were found to be about Tk. 266929, Tk. 161,792 and Tk. 116,831 in Kushtia whereas it was about Tk. 282,035 , Tk. 165,378and Tk. 118,476 in Jhenaidah district. The rate of return over variable cost was estimated at 2.53 and over total cost were 1.78 in Kustia district whereas it were 2.42 and 1.72 in Jhenaidah district. This implies that onion production is a profitable enterprise in both districts and variation existed among the onion producers within and between Kushtia and Jhenaidah district. The average per hectare yield of onion was estimated at about $11573.3 \mathrm{~kg}$ in Kushtia and about $12315.0 \mathrm{~kg}$ in Jhenaidah district. The BCR of onion production were 2.02 and 1.83 over total cost in Kushtia and Jhenaidah district respectively which indicates that onion production is profitable in both districts. The estimated DRC were 0.47 in Kushtia and 0.52 in Jhenaidah, implying that, Bangladesh has comparative advantage in onion production than other countries. In Cobb-Douglas production function, it evaluates that the farm area, irrigation, pesticide, seed, TSP and lab or have positive and significant impacts on onion production and shows constant return to scale. Most of the producers faced several problems in onion production due to high price of inputs, lacking of modern technology and market regulation. Therefore, policy makers and government should take necessary policies for the development of onion production in Bangladesh.

\section{References}

Ali, M. A., Hossain, M. M., Zakaria, M., Hossain, T., Naznin, A. and Islam, M. M. 2015. Effect of GA3 on Quality Seed
Production of Onion in Bangladesh. Ecofriendly Agricultural Journal, 8(03):4750 .

Anik, A. R. and Salam, M. A. 2015. Determinants of adoption of improved onion variety in Bangladesh. Journal of Agriculture and Environment for International Development, 109(1):71-88.

Anisuzzaman, M., Ashrafuzzaman, M., Ismail, M. R., Uddin, M. K. and Rahim, M. A. 2009. Planting Time and Mulching Effect on Onion Development and Seed Production. African Journal of Biotechnology, 8(3):412-416.

Banani, A., Mustadjab, M., and Syafria, D. K. 2013. Production Management and Technical Efficiency of Red Onion Farming in Brebes Regency. Journal of Basic and Applied Scientific Research, 3(3):85-90.

Bapari, M. Y., Chowdhury, M.K.I., Haque, M. E. and Al-Mamun, A. 2016. Economic Analysis of Onion Production in Sujanagar and Santhia Areas of Pabna, Bangladesh. International Journal of Humanities and Social Science Invention, 5(10):5-12.

Baree, M. A. 2012. Measuring Technical Efficiency of Onion (Allium cepa L.) Farms in Bangladesh. Bangladesh Journal of Agricultural Research, 37(1):171-178.

BBS 2008.Bangladesh Bureau of Statistics, Statistical Yearbook of Bangladesh, Statistics Division, Ministry of Planning, Government of the People's Republic of Bangladesh, Dhaka.

BBS 2015.Bangladesh Bureau of Statistics, Statistical Yearbook of Bangladesh, Statistics Division, Ministry of Planning, Government of the People's Republic of Bangladesh, Dhaka.

BBS 2016.Bangladesh Bureau of Statistics, Statistical Yearbook of Bangladesh, Statistics Division, Ministry of Planning, 
Government of the People's Republic of Bangladesh, Dhaka.

Bose, T. K. and Som, M. G. 1990. Vegetable crops in India. Naya Prokash, Calcutta, 6:545-582.

Bruno. M. 1965. The Optimal Selection of Export-Promoting and Import Substituting Projects. In planning the External Sector: Techniques, Problems and Policies, New York, United Nations.

Grema, I. J., and Gashua, A.G. 2014. Economic Analysis of Onion Production along river Komaduga Area of Yobe State, Nigeria, IOSR. Journal of Agriculture and Veterinary Science, 7(10):5-11.

Haile, B. T. 2015. Determinants of Technical, Allocative and Economic Efficiencies among Onion Producing Farmers in Irrigated Agriculture: Empirical evidence from Kobo District, Amhara Region, Ethiopia, African Journal of Agricultural Research, 10(20): 2180-2189.

Hasan, M. K. Islam, M. S. and Miah, M. A. M., 2009. Returns to Investment in Summer Onion Research and Extension in Bangladesh, Bangladesh Journal of Agricultural Economics,32(1\&2) 49-61.

Hasan, S. 2010. Economic Study on Onion Production in Selected Areas of Bangladesh, M.S. Thesis, Department of Agricultural Economics, Bangladesh Agricultural University, Mymensingh.

Haque, M. A., Miah, M. A. M., Hossain, S., Rahman, M. S. and Moniruzzaman, 2011. Profitability of Onion Cultivation in Some Selected Areas of Bangladesh, Bangladesh Journal of Agricultural Research, 36(3):427-435.

Hossain, M. M., Abdulla, F. and Farvez, I. 2017. Time Series Analysis of Onion production in Bangladesh, Innovare Journal of Agricultural Science, 5(1):1-4.

Ismail, A. G., Gharleghi, B., Jafari, Y., Hosseinidoust, E. and Shafighi, N. 2009.
The Impact of Domestic Resource Cost on the Comparative Advantages of Iran Crude Steel Sector, Munich Personal RePEc Archive Paper No. 26381, posted 4. November 2010 18:26 UTC.

Krueger, A.O. 1966. Some Economic Costs of Exchange Control: The Turkish Case, Journal of Political Economy, 74:466480.

Mahmood, S. M. Q. 1995. Marketing of Selected Spices in Comilla District of Bangladesh. M.S. Thesis, Department of Agricultural Economics, Bangladesh Agricultural University, Mymensingh.

Mari, F.M. and Lohano, H. 2007. Measuring Production Function and Technical Efficiency of Onion, Tomato, and Chilies Farms in Sindh, Pakistan. The Pakistan Development Review, 46(4):1053-1064.

Miah, M. A. M. and Rashid, M. A. 2015. Profitability and Comparative Advantage of Oilseed Production in Bangladesh. Bangladesh Development Studies, 38(3):35-54.

Monke, E. 1981. The Calculation of Domestics Resource Cost (DRC) and Net Social Profitability, Economics Working Series Paper 28, University of Arizona, USA

Pathak, C.S. 2000. Hybrid Seed Production in Onion. Journal of New Seeds, 1:89-108.

Shaha, P. K., 1999. An Economic Analysis of Production of Different Varieties of Onion in a Selected Area of Pabna, M.S. Thesis, Department of Agricultural Economics, Bangladesh Agricultural University, Mymensingh.

Stryker, J. D. 2009. Domestic Resource Cost Analysis of Azerbaijan, Private Sector Competitiveness Enhancement Program in Azerbaijan, USAID Prime Contract No. AID-112-C-08-00002.

Yercan, M. and Isikli, E. 2009. Domestic resource cost approach for international competitiveness of Turkish horticultural products. African Journal of Agricultural Research, 4(9):864-869. 